\title{
Fé na ciência? Como as famílias de micro viram a ciência do vírus Zika acontecer em suas crianças no Recife/PE
}

Faith in science? How families saw the science of the Zika virus happen to their children in Recife/PE

\section{Soraya Fleischer}

\section{(2) OpenEdition Journals}

\section{Edição electrónica}

URL: https://journals.openedition.org/aa/9448

DOI: $10.4000 /$ aa. 9448

ISSN: 2357-738X

\section{Editora}

Programa de Pós-Graduação em Antropologia Social (UnB)

\section{Edição impressa}

Paginação: 170-188

ISSN: 0102-4302

\section{Refêrencia eletrónica}

Soraya Fleischer, «Fé na ciência? Como as famílias de micro viram a ciência do vírus Zika acontecer em suas crianças no Recife/PE», Anuário Antropológico [Online], v.47 n. 1 | 2022, posto online no dia 31 janeiro 2022, consultado o 24 julho 2022. URL: http://journals.openedition.org/aa/9448 ; DOI: https:// doi.org/10.4000/aa.9448

\section{(c) (i) (2)}

Creative Commons - Atribuição-NãoComercial-SemDerivações 4.0 Internacional - CC BY-NC-ND 4.0 https://creativecommons.org/licenses/by-nc-nd/4.0/ 


\section{Anuário Antropológico}

v.47 n.1 | 2022

2022/v.47 n.1

Fé na ciência? Como as famílias de micro viram a ciência do vírus Zika acontecer em suas crianças no Recife/PE

Faith in science? How families saw the science of the Zika virus happen to their children in Recife/PE

\section{Soraya Fleischer}

\section{OpenEdition \\ Journals}

\section{Edição electrônica}

URL: http://journals.openedition.org/aa/9448

DOI: $10.4000 /$ aa. 9448

ISSN: 2357-738X

\section{Editora}

Programa de Pós-Graduação em Antropologia Social (UnB)

\section{Referência eletrônica}

Soraya Fleischer, «Fé na ciência? Como as famílias de micro viram a ciência do vírus Zika acontecer em suas crianças no Recife/PE», Anuário Antropológico [Online], v.47 n.1 | 2022. URL: http://journals. openedition.org/aa/9448; DOI: https://doi.org/10.4000/aa.9448

\section{ब(1) $\Theta \Theta$}

Anuário Antropológico is licensed under a Creative Commons. Atribuição-SemDerivações-SemDerivados CC BY-NC-ND 


\title{
Fé na ciência? Como as famílias de micro viram a ciência do vírus Zika acontecer em suas crianças no Recife/PE
}

Faith in science? How families saw the science of the Zika virus happen to their children in Recife/PE

DOI: https://doi.org/10.4000/aa.9448

\author{
Soraya Fleischer \\ Universidade de Brasília - Brasil \\ Professora do Departamento de Antropologia, Instituto de Ciências Sociais, Universidade de Brasília, Bra- \\ sília/DF, Brasil. Doutora em Antropologia pela Universidade Federal do Rio Grande do Sul (2007) e com um \\ recente estágio pós-doutoral também em Antropologia na Universidade Federal de Santa Catarina (2022). \\ Co-coordena o Coletivo de Antropologia e Saúde Coletiva (CASCA) e o podcast Mundaréu.
}

O vírus Zika (VZ) se instalou no Brasil como uma nova epidemia entre os anos de 2015 e 2016. Sua principal consequência foi reprodutiva, com o nascimento de mais de 4.000 crianças com o que se convencionou chamar de Síndrome Congênita do Vírus Zika (SCVZ), que reúne um conjunto complexo de muitas deficiências e exige vários tipos de cuidado especializado. Até o momento, na literatura antropológica, muito foi dito sobre essas deficiências, sobre o cotidiano de cuidados e de direitos dessas crianças e suas famílias, mas nem tanto foi documentado sobre a relação que elas mantiveram com a ciência que por muito tempo tentou compreender esse novo vírus, essa nova síndrome. 0 artigo apresenta razões para essas pessoas terem aceitado os convites vindos da ciência e também terem tecido reflexões mais críticas sobre esse intenso convívio com a mesma. Com base em pesquisa coletiva e etnográfica, realizada ao longo de quatro anos no Recife/PE, epicentro da epidemia do VZ, o artigo pretende contribuir com uma Antropologia da ciência menos "interna ao laboratório", já que os sujeitos de pesquisa envolvidos na produção de conhecimento sobre o VZ e a SCVZ também ajudaram a avaliar e - mais importante - a construir essa ciência.
The Zika virus (ZV) arrived in Brazil as a new epidemic between the years of 2015 and 2016. Its main consequence was reproductive, with the birth of more than 4,000 children with what was called the Congenital Zika Virus Syndrome (CZVS), a complex set of disabilities that requires a range of specialized care. So far, in the anthropological literature, much has been said about these disabilities, about the daily care and rights of these children and their families, but not so much has been documented about the relationship they had with science that tried to understand this new virus, this new syndrome. The article discusses why this specific population accepted the invitations coming from science and their critical reflections on this intense interaction with science. Based on a collective and ethnographic along four years of research in Recife/PE, the epicenter of the ZV epidemic, the article intends to contribute to an Anthropology of science less "internal to the laboratory", since the research subjects involved in the production of knowledge about the ZV and CZVS also helped to assess and - most importantly - construct this science.

Zika Virus Epidemics; Recife; Anthropology of science. 


\section{Introdução: o vírus, a síndrome e a ciência}

O vírus Zika (VZ) se instalou no Brasil como uma nova epidemia entre os anos de 2015 e 2016, sobretudo. Sua principal consequência foi reprodutiva, com o nascimento de mais de 4.000 crianças com o que se convencionou chamar de Síndrome Congênita do Vírus Zika (SCVZ). Do ponto de vista da Antropologia, muito foi estudado e publicado sobre as crianças e suas famílias, mas nem tanto foi documentado sobre a ciência do VZ e do SCVZ. As poucas obras recentes das Ciências Sociais sobre a ciência do VZ tendem a priorizar as cientistas envolvidas diretamente nessa produção, os nomes que se laurearam, mais cedo ou mais tarde, com as descobertas desbravadoras (Diniz 2016, Löwy 2019). Para além das cientistas nacionais, internacionais e renomadas, houve um grande conjunto de cientistas mais locais e desconhecidas, que atuaram nos serviços de saúde e nas universidades da Região Metropolitana do Recife (RMR), epicentro epidemiológico do VZ naquele biênio. Essas últimas pouco apareceram nessa história recente e hagiográfica da dita ciência com "C" maiúsculo (Latour 2000).

E há ainda outros atores, como as crianças infectadas pelo VZ e as famílias que cuidam da SCVZ, que raramente foram abordadas nos estudos sobre a ciência do VZ. Como lembraram Rabeharisoa e Callon, "as questões relativas às relações entre cientistas e não cientistas, especialistas e leigos - especialmente na produção e difusão do conhecimento - têm recebido pouca atenção do ponto de vista empírico ou teórico, pelo menos até recentemente" (2003, 194, tradução livre). Esses autores sugerem que os estudos da ciência, ao se concentrarem em conhecer os laboratórios e as suas cientistas, acabam ficando "muito internos à ciência" (2003, 193). Mas, quando apareceram na produção antropológica, as famílias atingidas pela epidemia foram geralmente consideradas pela "ciência doméstica" que produzem (Diniz 2016, Barros 2021). Quer dizer, aquele conhecimento que parte da intimidade e convivência intensificada com essas crianças no espaço da casa e do cotidiano de cuidados (Pols 2014).

Considerar a relação da casa com a clínica e a ciência é importante porque, justamente, as profissionais de saúde e as pesquisadoras compõem um conjunto de atores com o qual as famílias conviveram intensamente. Esse também é o caso de pacientes raros e seus familiares cuidadores, como mostraram Rabeharisoa e Callon $(2003,195)$ e seus colegas que vêm estudando o envolvimento de pacientes com a ciência (Rabeharisoa et al. 2014, Nunes et al. 2010, Moreira 2014, Moreira et al. 2014). Esse tem sido um movimento desde os meados do século XX. Antropólogos na França, Portugal e Inglaterra têm testemunhado os muitos intercâmbios de saberes de pacientes, associações de pacientes e as pesquisadoras. Por exemplo, a partir de sua etnografia com a Associação Francesa contra as Miopatias (AFM), Rabeharisoa e Callon notaram que, num contexto mais amplo, das 156 organizações que eles mapearam na virada do século, “34\% financiavam pesquisas” (2002, 59). Eram grupos pequenos que priorizavam o recurso para a ciência e, na média, à época doavam $40 \%$ de seu orçamento à pesquisa (idem).

As associações de famílias, que surgiram na Região Metropolitana do Recife logo no início da epidemia do VZ, tinham objetivos semelhantes às associações de 
pacientes em outras partes do mundo, "elaborar uma identidade coletiva", "apoiar a sua integração social", "trazer a patologia ao espaço público" (Rabeharisoa e Callon 2002, 58) e garantir a sobrevivência das crianças com a SCVZ (Scott et al. 2017). A ciência foi buscada, acima de tudo, como uma prática de cuidado, para tentar encontrar respostas e melhoramentos para a saúde e a qualidade de vida dessas crianças. Mas, diferente das organizações de pacientes naqueles países europeus, não houve a participação, por exemplo, no desenho e no financiamento dos projetos de pesquisa ou algo como um "advocacy científico" (Rabeharisoa et al. 2012, 8). E, em termos de recursos, foi a ciência que eventualmente ofereceu oportunidades e doações às crianças com a SCVZ, suas famílias e ONGs ali no Recife, não o contrário.

Embora as famílias tenham procurado as especialistas para lidar com os sintomas específicos de seus filhos e filhas, muito mais frequentemente elas foram contatadas pelas pesquisadoras (Rabeharisoa . 2012, 20-1). As famílias foram encontradas pelos prontuários médicos das instituições de saúde por onde haviam passado. Também por intermédio das ONGs que, nas reuniões presenciais e nos grupos de WhatsApp, retransmitiam os convites recebidos das cientistas. Ainda que as associações comunitárias tenham sido anfitriãs da ciência do VZ, exercendo um papel informal no recrutamento de sujeitos de pesquisa, a adesão e o relacionamento com as cientistas se deram de modo individual e familiar. Então, a literatura com a qual dialogarei neste artigo servirá parcialmente, sempre tendo em vista que, no cenário da RMR, o relacionamento com a ciência foi, à primeira vista, "mais reativo do que proativo" (Rabeharisoa et al. 2012, 20) e foi mais atomizado do que coletivo.

Ainda assim, os nossos dados da RMR apontam para ainda outra forma de diálogo com a ciência. ${ }^{1}$ As interlocutoras que conhecemos tinham muito a dizer sobre a ciência biomédica que encontraram nos últimos anos. Embora estivessem, a todo tempo, produzindo reflexões sobre seus aprendizados com as crianças (a "ciência doméstica"), elas também foram acumulando impressões e amadurecendo opiniões sobre a forma com que as cientistas abordaram e se relacionaram com essas crianças. ${ }^{2}$ Aqui, evitaremos separar a casa da clínica, a mãe leiga da profissional especialista, a objeto observado do sujeito observador. A aposta, para ficar menos "interna ao laboratório" (Rabeharisoa e Callon 2003), é que esses sujeitos de pesquisa mergulharam intensamente na pesquisa e, mesmo que de uma perspectiva diferente da dos sujeitos pesquisadores, ajudaram a avaliar e - mais importante - a construir essa ciência. Ao trazer para o debate outros sujeitos que também produziram a ciência do VZ ali no Recife, aliamo-nos aos que discutem o fato de que "as teorias do conhecimento e as relacionadas "hierarquias de evidências' sejam frequentemente associadas ao movimento da medicina baseada em evidências" (Moreira et al. 2014, 175). Sugerimos que outras evidências, produzidas por quem viu essa ciência ser feita de perto, sejam também pertinentes.

Aqui partimos da ideia de que ciência é um assunto de todo mundo, mesmo que não sejam cientistas de bancada (como nós da Antropologia), mesmo que não sejam da universidade (como as mães e suas crianças com a SCVZ). Isso é
1 Essa pesquisa etnográfica foi realizada ao longo de um quadriênio (2016-2019). Os dados foram construídos de encontros, conversas, entrevistas, observações, reuniões, fotografias e contou com o apoio do CNPq, PIBIC, Departamento de Antropologia e Fundação de Empreendimentos Científicos e Tecnológicos / UnB. Agradecemos às dezenas de famílias, crianças e cientistas que nos contaram suas vivências com o VZ e a SCVZ, à equipe de 23 pesquisadoras da UnB e à aprofundada leitura crítica oferecida ao texto pelas colegas do Núcleo de Antropologia do Contemporâneo (TRANSES), coordenado por Sônia Maluf, minha supervisora de pós-doutorado no PPGAS/UFSC ao longo de 2021.

2 Utilizaremos o plural feminino porque, na grande maioria, eram mães, ativistas, pesquisadoras, estudantes, professoras, acadêmicas a tentarem entender e atender as crianças com a SCVZ. 
particularmente importante no caso brasileiro, já que a ciência produzida aqui é, em geral, financiada por dinheiro das contribuintes. Sendo pública, a ciência também deve prestar contas, explicar o que e por que faz o que faz. E diferentes espelhamentos sobre a ciência podem ser úteis para que os seus caminhos sejam evidenciados e aprimorados. ${ }^{3} \mathrm{Na}$ primeira parte, situaremos a cena científica do VZ/SCVZ no Recife, com suas pesquisadoras e jornalistas, para descrever, em seguida, os tipos de relações que com elas foram estabelecidas de "ajuda", "recompensa" e "parceria". Na segunda parte, três principais queixas em relação à ciência serão apresentadas para demonstrar como é complexo e delicado esse cenário, sobretudo à luz de quem recebe a ciência na própria pele. Com isso, optaremos por uma maior flexibilidade, em vez de fixidez, de uma tipologia que vem em curso (Rabeharisoa e Callon 2002) sobre a forma de leigos e peritos se relacionarem na produção da ciência.

\section{As doutoras da Grande Recife}

A ciência logo se mobilizou para entender a quantidade, muito acima da média recente, de nascimentos de crianças microcefálicas ${ }^{4}$. Depois de alguns meses, foi crescendo um consenso de que o VZ era o responsável principal pela microcefalia (Löwy 2019). Então, durante os anos epidêmicos (2015-2016) e os anos que se seguiram (2017-2019), a ciência que chegou ali na RMR foi, majoritariamente, uma ciência do VZ, eventualmente também uma ciência da SCVZ. ${ }^{5}$ Vejamos como e por meio de quem essa ciência ali chegou.

No Recife, centenas de cientistas foram apresentadas ou abordaram diretamente as mulheres responsáveis pelas crianças com a SCVZ. Certa tarde, em uma sala de espera de uma clínica de reabilitação, a nossa equipe acompanhava quatro mães e seus filhos nas cadeiras de rodas. E perguntamos se já tinham participado de pesquisas. Todas disseram que sim, "foi pesquisa demais". Uma delas disse que "participou de tanta pesquisa, assinou tanto termo ${ }^{6}$, que se cada papel que ela assinasse fosse um real ela já estaria rica". Perguntamos onde tinham acontecido essas pesquisas e explicaram que foi "em tudo que é faculdade". Mas, pelo que notamos, vários outros lugares serviram de cenário para essa ciência acontecer: associações comunitárias, hospitais, clínicas de fisioterapia e até nas casas dessas interlocutoras, por exemplo. E, como a RMR concentrava os principais serviços dedicados a essas crianças, muitas famílias vieram do interior do estado para realizar parto, consulta, exame, terapia e, nessas ocasiões, também foram convidadas pelas pesquisadoras. Então, a ciência não precisou pegar a estrada e fazer uma "busca ativa" pelos municípios mais distantes da capital, os sujeitos de pesquisa vieram até suas agulhas, caixas de isopor e questionários.

Essa presença intensa e essa variedade de espaços ajudou a amalgamar alguns atores, como profissionais de saúde, pesquisadoras, professoras, residentes, estagiárias, estudantes etc. Muitas vezes, uma mesma pessoa atendia como médica em um consultório e realizava pesquisa na universidade onde era também professora. Clínica, ciência e docência são atribuições comuns nas áreas da saúde. Por isso, um encontro entre uma mulher, sua criança e essa profissional poderia
3 Referimos à ciência no singular, sem o intuito de essencializar nem criar uma ideia única do empreendimento científico, mas como um retrato generalizado de iniciativas de pesquisa de várias áreas que chegaram à região. No intervalo do biênio da epidemia (2015-2016), encontramos, na Plataforma Brasil, 99 projetos de pesquisa realizados por pesquisadoras locais na RMR (Simas 2020).

4 A microcefalia se dá quando, ao nascer, o diâmetro craniano é inferior a $32 \mathrm{~cm}$. No caso do VZ, é um dos sintomas da SCVZ. As famílias utilizavam o adjetivo, "micro", de modo generalizado para identificar a criança, os especialistas e os serviços que Ihes atendiam (ver a "Introdução" de Fleischer e Lima 2020). 5 A ciência priorizar o VZ era um problema para as famílias, já que algumas não concordavam que a microcefalia fosse causada por um vírus (Fleischer, no prelo). Além disso, a maioria achava que a síndrome deveria ser a prioridade da pesquisa e não um mosquito, um microrganismo, a transmissão vertical. 6 Termo de Consentimento Livre e Esclarecido (TCLE).

7 Essa sala de espera foi toda descrita no diário de campo de Aissa Simas, 2018. Faremos referência apenas aos trechos de outras pesquisadoras da equipe, enquanto os demais registros foram produzidos por mim. A partir das sete visitas realizadas à RMR, escrevemos 1.800 páginas de diários de campo que, em uma versão editada, acordamos poderem ser compartilhadas pela equipe de pesquisa. 
ter diferentes finalidades, a realização de um exame para o fechamento de um diagnóstico, o acompanhamento clínico continuado, a coleta de uma amostra de sangue para um projeto de investigação. Se, na área da saúde, é comum a multivinculação institucional, parece que a urgência da epidemia acentuou esse amálgama entre perfis profissionais. Por exemplo, naquela mesma sala de espera descrita acima, quando perguntamos sobre a diferença entre "médico" e "cientista", uma das mães explicou: "No começo do surto, as mães estavam desesperadas, sem saber o que era nem o que fazer. Aí, pra cada médica, vinham três pesquisadoras junto, e não davam informação, não diziam o que estavam fazendo. Então, as mães não conseguiam diferenciar".

Essa mãe também explicou que, por vezes, não houve convite para integrar uma pesquisa. Do prontuário e dos exames, já derivavam dados, números, medições incluídos posteriormente na amostra em construção pela pesquisadora. Mas, em geral, nossas interlocutoras contaram que foi feito um convite mais formal, criando um enquadramento diferente da consulta, e credenciais foram apresentadas, TCLEs foram assinados, consentimentos foram garantidos. Apesar dos espaços, chapéus e formatos da relação, com mais ou menos formalidade, foram tantas as ocasiões em que o olhar científico foi lançado para essas crianças que, algumas vezes, ao voltarmos ao Recife, uma ou outra mulher não nos reconhecia, não se lembrava de nossa pesquisa especificamente. Éramos também parte do amálgama, Antropologia grudava na Medicina, cadernos de campo pareciam com pranchetas e formulários, perguntas poderiam ser de um roteiro qualitativo ou de uma reportagem.

Assim, para traduzir esse amálgama sugiro utilizar uma categoria difusa, mas distinta o suficiente para captar a aura de prestígio e exotismo que a cerca. "Doutora" podia ser, a um só tempo, médica, cientista de bancada, chefe de um ambulatório, pesquisadora de campo e/ou docente universitária. Nesse sentido, a doutora era ligada ao mundo da escolaridade, dos títulos, da especialização. Mas também, noutro sentido complementar, a doutora poderia ser, como chamavam localmente, a "bacana", uma autêntica representante da elite recifense e pernambucana, que exibia o dourado de seus cabelos e de suas joias, o salto alto de seus stilettos, as longas unhas de silicone, a marca de biquini de quem frequentava a cobertura, o clube ou a praia.

Outro conjunto de profissionais, as jornalistas, também foram aproximadas das pesquisadoras. Não exatamente por conta dos desdobramentos de seu ofício, mas pela curiosidade e pela metodologia adotada. Naquela mesma sala de espera, aproveitamos para perguntar se viam diferença entre jornalista e pesquisadora e, em rápido uníssono, disseram: "Não tem diferença". Sempre havia termos para assinar, seja o TCLE, seja o assentimento de uso de imagens. Uma "entrevista" poderia ser dada a uma repórter ou a uma pesquisadora. "Tem diferença porque, para vocês [e aqui, as antropólogas eram incluídas], é pra estudo e pra eles é pra mídia, mas todos fazem as mesmas perguntas: se foi Zika, por que foi, o que aconteceu, como os serviços estão tratando", uma das mulheres explicou. Outra, sentada ao seu lado, complementou ironicamente, "Os dois fazem as mesmas perguntas. Dá 
vontade de colocar um gravador e gravar tudo e dar pra eles para não ter que responder tudo de novo". E todas caíram no riso. Ficamos sabendo, inclusive, de algumas equipes locais que entendiam bem essa crítica e tentavam convergir instrumentos e bancos de dados para evitar a exaustão das interlocutoras.

Mas também havia certas diferenças. Outra mulher nos contou, valorizando a visibilidade imediata da mídia, "A minha filha é famosa, já fez ensaio de fotos para duas revistas, uma norte-americana e outra francesa. Apareceu em outdoor e tudo, ela foi até reconhecida na rua por um gringo". ${ }^{8}$ Já Cíntia, uma interlocutora que assim chamaremos e com quem tivemos intenso contato, explicou, mais entusiasta com a ciência do que com o jornalismo: "A maior diferença entre uma jornalista e uma pesquisadora é a continuidade. A jornalista tem um assunto que ela quer saber para a matéria. Então, ela vai, pergunta sobre esse assunto e vai embora. A relação com pesquisadoras é diferente, tem o acompanhamento a longo prazo. Tenho até amizade com algumas pesquisadoras".

Nos últimos anos, essas mulheres tiveram um contato intensificado com a ciência, experiência pouco usual para a maior parte de nós. Essa experiência é valiosa, ao mesmo tempo como uma mirada interna à ciência (porque se tornaram sujeitos de pesquisa) e externa (porque não se tornaram sujeitos pesquisadores). Elas têm muito a dizer à ciência e suas cientistas, bem como a uma Antropologia da ciência. Nesse sentido, tentaremos compreender o que elas disseram, em nome de seus filhos e filhas, sobre a ciência do VZ e da SCVZ, mas não a partir da “ciência do doméstico" (Diniz 2016, Pols 2014), nem como um ativismo coletivo de pacientes e cuidadoras (Rabeharisoa e Callon 2002, 2003, Rabeharisoa et al. 2012), como tem sido mais comum até agora. De outra perspectiva, considerando-as como sujeitos e acompanhantes de sujeitos de pesquisa, a seguir, mostraremos algumas das razões para valorizar e as formas de se aproximar da ciência. Depois, detalharemos algumas das principais formas com que essa convivência aconteceu. E, por fim, discutiremos por que o valor da ciência vem, pouco a pouco, se desestabilizando para essas famílias atingidas por essa epidemia.

\section{A fé na ciência}

As famílias entenderam que a "cabeça pequena" não era uma novidade só para elas, mas também que vários outros atores, as doutoras em especial, queriam entender o que estava acontecendo. E elas se dispuseram a apresentar seus filhos e filhas, a descrever seus comportamentos cotidianos, a responder perguntas e, principalmente, permitir que seus corpinhos fossem examinados, na superfície e em seu interior. A matéria-prima e as respostas vieram das cuidadoras e das crianças, já as perguntas e as conclusões, das cientistas e jornalistas. A ciência foi alçada ao posto de estudar, entender e explicar o mundo. Para muitas dessas famílias, a ciência já era e se manteve como uma prática importante, respeitada e desejada. Ocupava, portanto, um lugar positivo, mas um lugar alheio e alhures, produzido por outras pessoas (que não vivenciavam o VZ e a SCVZ de perto) a partir dessas pessoas (que a vivenciavam de muito perto). Por conta desse "grande divisor" (Latour 2000, 377) entre sujeitos e objetos de pesquisa, era preciso que
8 Diário de campo de Thais Souza, 2017 
os segundos delegassem aos primeiros a atribuição de serem estudados. Nossas interlocutoras concordaram com essa distribuição do trabalho, no marco desse "modelo de delegação", no qual "os pacientes, reconhecendo seu desconhecimento, deixam a cargo de cientistas e especialistas a escolha das linhas de pesquisa a serem priorizadas e apoiadas, bem como a forma de lidar com a produção e distribuição de conhecimentos teóricos e práticos” (Rabeharisoa e Callon 2002, 60).

A ciência foi vista como aquela que sai do conforto de seus laboratórios e vai conhecer o mundo para descrever a "realidade". Várias mães compreenderam que as doutoras teriam esse compromisso de olhar para as coisas com seriedade, neutralidade, precisão. Para Camille, uma das mães de micro que visitamos muitas vezes, a ciência contrapõe o que circula por outros canais, como as redes sociais: "Não dá para acreditarmos em tudo que sai no Face, tudo que é postado, tudo que é dito no zap. É preciso sair do telefone, sair do Facebook e vir ver as pessoas, vir conversar. É preciso ver a realidade mesmo". Foi assim que ela interpretou a nossa saída de Brasília até o Recife, ou o que outros atores fizeram, como repórteres que foram a sua casa para fazer uma entrevista, uma pesquisadora que deixou a universidade para olhar para o seu filho em cima da maca etc. Acreditavam na ciência pelo seu movimento de instigação, curiosidade e, consequentemente, produção da verdade. Camille e outras cuidadoras tinham a ciência - e demais profissões que se baseavam no escrutínio do empírico - em alta conta.

Folhetos e manuais, vídeos na internet e palestras eram os formatos pelos quais as doutoras enunciavam o conhecimento sobre o VZ. Em 2018, assistimos a um seminário sobre doenças raras promovido por uma faculdade privada. Ao nosso lado, sentou-se Cintia e, com sua filha nos braços, ouviu atentamente a palestra de uma neurologista famosa da cidade, que também atendia essa sua caçula. No final de semana seguinte, fomos visitar a família e, caminhando pela sua rua, vimos passar um rapazinho pedalando freneticamente uma bicicleta, levando outro na garupa. O piloto estava usando um capacete de motocicleta, mas dava para entrever um largo sorriso, os dois amigos se divertindo muito com a velocidade. Cintia comentou, "esse daí tem microcefalia". Perguntamos se era esse tipo de folia que ela esperava para a filha. Ela imbricou os acontecimentos dos últimos dias:

Sim, é. Mas você viu aquela palestra da doutora? O grande problema das nossas crianças não é a microcefalia, não é a cabeça pequena, mas são as calcificações. É isso que faz a cabeça não funcionar muito bem, não é o tamanho pequeno dela. E ela falou, já vi ela falar disso em outras palestras, que ninguém sabe o quanto essas calcificações vão impactar a criança no futuro. $\mathrm{O}$ quanto a minha filha vai conseguir desenvolver.

Cintia foi, sem dúvida, a interlocutora que mais demonstrou seu entusiasmo com a ciência. Noutro dia, na terapia de sua filha, perguntamos como era sua relação com a ciência e a justiça, já que muitas foram as vezes que essas famílias tiveram que judicializar preconceitos e pleitos por medicamentos, cirurgias, etc. "Com certeza, tenho mais fé na ciência. A justiça tá desse jeito aí, que a gente não 
pode contar, não pode confiar. Tem muito político dentro da justiça já". E provocamos: "Mas você continua confiando mesmo sem receber os resultados?". "Continuo, claro", ela disse rindo, "Eu tenho fé de que vou ainda receber os resultados. Eu acredito mesmo que alguma coisa vai aparecer para a minha filha".

Numa de nossas visitas à casa de outra mãe, Mariana, comentamos que Mateus era muito tranquilo, ficava sossegado e pacífico no seu colo, ouvindo nossa conversa. Ela nos disse:

Nem sempre foi assim. Só agora que ele está mais tranquilo. No começo, ele chorava muito, muito. Teve uma noite que ele ficou de meia noite às $5 \mathrm{~h}$ da manhã chorando. Dormia uma meia hora e voltava a chorar. Todos os bebês da micro têm choro contínuo, convulsão, agora estão bronco-aspirando e passando a usar sonda. Estão fazendo as características da síndrome, sabe.

Quando a família disponibilizava o seu filho para participar de uma pesquisa, imaginava que as "características da síndrome" seriam listadas, descritas, explicadas a partir daquele caso e generalizadas para todos os outros casos com o mesmo diagnóstico. E, assim, identificar as características comuns foi importante para passar da microcefalia para o que se convencionou chamar de SCVZ, em que a pequena cabeça virou apenas um dos sintomas. Nesse sentido, Mariana e suas colegas esperavam que "fazer as características" da síndrome instruiria um cuidado mais preciso para o choro, a convulsão, a disfagia e a broncoaspiração que frequentemente acometiam esse público infantil.

Rabeharisoa e Callon, em seu estudo sobre a Associação Francesa contra as Miopatias, notaram "como os pacientes foram capazes de construir suas identidades individuais e coletivas devido ao intenso envolvimento da associação em atividades de pesquisa científica e tecnológica - um envolvimento que lhes permitiu mudar seu status ontológico" (2007, 231). Isso quis dizer, na prática, deixar o lugar onde por tanto tempo esses pacientes foram colocados - "freaks of nature" (aberrações da natureza) - para o lugar de seres humanos com deficiências explicadas por uma "falta genética". E foi a relação com a ciência, que descreveu as miopatias, que possibilitou essa "mudança ontológica" (idem). As crianças de micro, sobretudo no início de suas vidas, foram também desumanizadas, chamadas de "ET", "monstro" ou "filho do mosquito" ao redor dos bairros, ruas e ônibus da cidade. Essas famílias, ao receberem visitas das doutoras, ao terem as histórias e fotografias de seus filhos e filhas ilustrando artigos científicos, jornais de grande circulação ou até outdoors, foram navegando por outras compreensões sobre a microcefalia. Essas crianças, ao terem suas características sindrômicas descritas, passaram a fazer parte de um projeto de pesquisa, a interessar à ciência, até se tornarem "famosas", como lembrou aquela mãe, acima. Parece que a ciência, por um lado, contribuiu para trazer essas crianças de volta aos limites do humano, e um humano valorizado pela possibilidade, dentre tantas, de contribuir para o adensamento do conhecimento sobre a humanidade em seu contato com o VZ. Por outro lado, a ciência "socializou os pacientes" e "eles se tornaram partes in- 
teressadas nas redes científicas, clínicas, médicas e sociais", levando-os "de uma situação de exclusão a uma de inclusão" (Rabeharisoa e Callon 2007, 240).

Conhecer melhor essas crianças - "ver a realidade", "fazer as características", "falar nas palestras" e "fazer alguma coisa aparecer" - são informações que as famílias esperavam receber de volta da ciência. Mariana nos disse, em outra visita que lhe prestamos: "Já que a pesquisa de vocês vai chegar no governo, acho que eles têm que dar mais ajuda. O medicamento tem muita dificuldade para conseguir. O medicamento do Mateus é barato e eu posso pagar. Mas tem os suplementos, tem leite que custa $\mathrm{R} \$ 100$ a lata, imagina”. Depois, nós a acompanhamos numa longa entrevista que deu a uma ONG internacional de direitos humanos. No caminho de volta pra casa, ela explicou que, mesmo que aquela conversa com a jornalista estrangeira não servisse imediata ou diretamente ao Mateus, "é sempre bom poder ajudar outras pessoas, explicar sobre a situação dos bebês que eu conheço, contribuir para que o governo melhore sua atuação".

Sobretudo no início de nosso contato com essas famílias, ficou muito clara essa postura ativa no atendimento aos convites da ciência e da mídia. As famílias desejavam, acima de tudo, entender melhor as crianças e realmente confiaram que as pessoas estudadas e diplomadas deteriam o conhecimento, os recursos, a infraestrutura e as redes de contatos necessários para avançar e ampliar esse entendimento. Foi a vontade de saber e a fé de que a ciência produziria esse saber que motivaram muitas dessas famílias a autorizarem a participação de seus filhos e filhas nas pesquisas. Saber mais permitiria que, numa escala local, essas famílias

conseguissem cuidar melhor de seus filhos e, numa escala mais ampla, o governo, como sugeriu Mariana, "melhorasse sua atuação" junto a esse público com SCVZ. A ciência e a mídia eram compreendidas como fonte de informação e mediação entre o cidadão e o Estado.

\section{$4 \quad$ Ajuda, recompensa e parceria}

As interlocutoras logo entenderam que as doutoras, embora com autoridade para pesquisar e se pronunciar, precisavam ter acesso às crianças, aos seus sintomas. Então, as crianças viraram, concretamente, o corpus empírico da ciência do VZ, e, por isso, as famílias diziam que essas crianças estavam "ajudando" a ciência e a mídia. Eram também, portanto, atores desse amplo cenário, atuando como coprodutores desses empreendimentos. Cintia, por exemplo, nos disse que quase sempre as jornalistas lhe davam alguma coisa em troca, dinheiro, leite, fraldas. Ela aceitava, mas não cobrava de antemão para dar uma entrevista como via outras pessoas fazerem. E nos explicou, "Não é comprado, é uma ajuda". E acrescentou ainda, "Tem mãe que diz, 'Ah, pra que eu vou ficar dando entrevista? Não tô ganhando nada nada com isso'. Mas ganha, ganha sim. Ganha voz”. ${ }^{9}$

9 Diário de campo de Aissa Simas, 2018 Depois, lembrou de uma vez que contribuiu com uma reportagem televisiva e no dia seguinte recebeu a ligação de um centro de reabilitação oferecendo uma vaga para sua filha. Andreia, outra interlocutora muito próxima, explicou como via sua participação científica, "Elas vêm, querem saber do nosso trabalho, o que a gente faz com nossos filhos. A gente recebe, responde, achando que pode ajudar 
as outras mães a não se perderem da luz". Havia interesse próprio; tinham vontade de passar esperança para outras mães; e também faziam um investimento mais amplo, ao integrar uma pesquisa e contribuir para visibilizar a epidemia, o VZ e a SCVZ. Ao ajudar, havia um certo altruísmo em fazer aprendizados individuais chegarem mais longe, seja para as outras mães, seja para as autoridades.

Profissionais da mídia tinham por costume pagar por essas ajudas. Cachês foram oferecidos pelas fotografias, filmes, depoimentos. Bela nos contou que aceitou viajar com o filho até outra região e participar de uma campanha da prefeitura contra o mosquito Aedes aegypti, e recebeu $\mathrm{R} \$ 2.000 \mathrm{em}$ troca. Aparecer em telejornais ou em outdoors poderia mobilizar campanhas de doações de alimentos para a comunidade da micro como um todo. Uma pesquisa dos EUA, que previa construir dados a partir de uma coorte quinquenal com essas crianças, oferecia uma cesta básica por mês a cada família participante, Bela e Cintia eram integrantes, inclusive. Uma mulher nos contou que recebeu um auxílio de $\mathrm{R} \$ 1.000$ do fundo de pesquisa de uma cientista estrangeira que veio a Recife. Passagens de ônibus para ir e voltar e lanches para passar o dia durante uma coleta de sangue já eram condições naturalizadas, nem sequer precisando ser negociadas. Essas mulheres chamavam tudo isso de "recompensas", e algumas interlocutoras, pressionadas pelos seus companheiros e parentes, ao longo do tempo decidiram que só sairiam de casa para "ajudar" se as "recompensas" estivessem claramente garantidas já no início do contato com a jornalista ou a pesquisadora.

Entendemos que as recompensas chegavam em troca de ajuda individual, como Cíntia, Bela e Andreia descreveram nos parágrafos acima, e, quando coletivas, eram chamadas de "parcerias". E, na relação com a ciência, à medida que as famílias foram entendendo seu timing próprio, com os seus resultados chegando apenas a longo prazo, a prática da parceria foi se apresentando como necessária. Algo muito ansiado pelas mães eram as consultas com especialistas, raras na cidade. A consulta poderia ser a porta de entrada para realização de exames de alto custo, amostras de medicamentos, terapias e cirurgias reparadoras, tecnologias assistivas (óculos, cadeiras de rodas, órteses etc.). Esses eram itens dificilmente oferecidos na rede pública ou cobertos pelos planos de saúde. Ana Caroline, uma importante liderança local, comentou em um evento realizado em uma universidade e destinado às gestoras do município: "Eu tô com mais de 50\% das crianças sem tratamento. A gente fica louca tentando fazer parcerias com a universidade, ganhamos uma sede, pretendemos montar um centro de reabilitação, mas é difícil”" Ela vinha notando que muitas vagas de terapia estavam, em 2017, se fechando para as crianças com deficiência neurológica grave, como era o caso das crianças com a SCVZ. Uma parceria com a universidade poderia acontecer, por exemplo, a partir da oferta de material orgânico da criança em troca de consultas de acompanhamento ou terapias de reabilitação. Nesse mesmo evento, outra liderança, Fernanda, levantou-se, pegou a mão da presidente de outra associação de pacientes raros que estava ao seu lado e disse: "Precisamos andar assim ó, de mãos dadas, com os estudiosos, o Estado, todo mundo. Essas mulheres vivem completamente à margem da sociedade, ninguém nunca olhou para elas. Então,
10 Diário de campo de Raquel Lustosa, 2017. 
eu estou muito feliz, apesar de tudo, em estar discutindo isso aqui com vocês". ${ }^{11}$

A criança com a SCVZ virou um sujeito valioso à ciência do VZ. Reconhecendo o potencial desse corpus empírico, as famílias tentavam aproveitar os projetos de pesquisa, sabendo que aconteciam dentro de instituições de saúde e de ensino, ambos de difícil acesso. Então, as propostas científicas vieram junto com oportunidades clínicas (Castro 2020), dentro de instituições públicas e também privadas. Essas oportunidades também eram notadas por lideranças, como Ana Caroline e Fernanda, que propunham arranjos interinstitucionais para que mais famílias pudessem ser atendidas, passando de uma ajuda individual a uma parceria coletiva. E apostavam que o material biológico alimentaria uma relação a ser continuada por mais tempo. Haviam aprendido sobre o tempo da ciência, que dependia de vários questionários, muitas consultas, sucessivas coletas e follow-ups. "Andar de mãos dadas", "somar" e "fazer parcerias", essas eram as estratégias que as famílias e suas representantes vislumbravam com a ciência, a universidade, suas doutoras.

A partir dessas três categorias - ajuda, recompensa e parceria -, as mães amadureciam uma etiqueta ética para a participação de suas crianças nas pesquisas. O interessante também é que todos esses termos sugeriam uma participação bastante ativa, comunicavam a forma como elas entendiam a demanda da ciência e, deliberadamente, se posicionavam diante dela. Como bem resumiu Andreia, "tem que ser bom para os dois lados". A partir da ajuda oferecida pelas crianças e suas famílias, essa conclusão de Andreia parece ser o pressuposto ético nativo para qualquer desdobramento, seja recompensa, seja parceria.

Contudo, Bela notava a diminuição da presença de jornalistas e cientistas nos anos mais recentes. Explicou que as famílias vinham recebendo menos convites e que as recompensas vinham escasseando. "Agora, só temos a esperança de alguma coisa mudar. Mas, às vezes, né, não muda nada”. A mudança poderia ser uma política pública, um novo benefício social, uma vacina contra o VZ, a cura da SCVZ ou, como ela aventava, nada disso. Mas Bela sabia, como também Cintia, Camille, Mariana, Andreia e outras mães aqui mencionadas, que embora a ciência ou a mídia tivessem a capacidade de influenciar resultados e decisões, as mudanças poderiam demorar bem mais do que o tempo da doação da fralda ou mesmo do tempo de vida daquela criança, por exemplo. E se as doutoras estavam dirigindo menos convites às famílias da SCVZ, o making e o timing da ciência também estavam interessando menos a essas famílias. A seguir, discutiremos uma gradativa perda de fé na ciência, que passamos a observar nas visitas seguintes a Recife.

\section{Três queixas em relação à ciência}

Continuemos seguindo as ideias de Bela. Numa tarde, enquanto esperávamos a consulta do seu filho, Bela nos contou que no dia anterior participara de mais uma reunião de um projeto de pesquisa com um organismo internacional. Nessas reuniões, ao lado de doutoras e jornalistas de todo tipo, ela representava a associação de mães que integrava. Perguntamos como era sua participação:
11 Diário de campo de Yasmin Safatle, 2017. 
assim, no meio de tanta autoridade, nem que eu poderia falar o que eu quisesse. Eu queria, mas não imaginava que eu poderia ser uma pessoa importante assim. Importante eu digo, assim, com status, com audiência, sabe. Eu não sabia que eu seria importante pelo que eu sou mesmo, pelo que eu vivo todo dia. É muito bacana também conviver com as pessoas que têm mais experiência do que eu.

Emendamos, "Mas com o seu filho, você tem mais experiência do que elas". Ela abriu um sorriso e rapidamente concordou: "Isso, você tem razão. É uma troca mesmo. Eu conto da minha experiência, elas falam da delas". Ao final da conversa, perguntamos que tipo de resultados ela previa nessa troca com aquele braço da ONU e as doutoras do hospital onde esse grupo de pesquisa se reunia. Para nossa surpresa, ela disse, cética: "Eu não tenho muita esperança de que elas vão realizar alguma mudança, a intenção delas é de melhorar, criar uma rede para ajudar as crianças, mas o SUS no papel é lindo, na prática, não". ${ }^{12}$ Então, conviver nesses espaços, estar próxima de autoridades e, ao mesmo tempo, ter reconhecida a sua própria experiência com a SCVZ do filho poderiam ser oportunidades de alçar seu status, sua imagem entre as colegas da associação, sua autoestima até. Porém, "sentir-se importante" talvez fosse uma sensação mais individual do que os resultados científicos realmente chegarem a ser incorporados pelo SUS, espaço frequentado pela comunidade que Bela representava.

Mas o SUS seria a ponta final de incorporação das tecnologias geradas pela ciência. Precisamos voltar um pouco no tempo e acrescentar mais algumas camadas dessa relação entre as famílias e as doutoras. Embora tenham conhecido muitas pesquisadoras gentis, médicas atenciosas, repórteres interessadas em suas histórias como, por exemplo, esse grupo do qual Bela participava, a relação com a ciência suscitou ruídos. Notamos três grandes queixas que se referem a práticas que começaram antes de a criança nascer e continuaram a embalar os protocolos científicos até mais recentemente. Anos e anos de pesquisa sobre o VZ e ainda seguiam sendo relatados desrespeitos, violências, alheamento e subalternização nos cenários científicos. Dado o intensíssimo itinerário terapêutico em nome da saúde dos filhos, elas vinham se tornado especialistas no SUS (Fleischer 2020b). Agora, sugerimos que foram também se tornando especialistas sobre a ciência do VZ que foi produzida a partir dos corpos e histórias dessas crianças. Nesse tempo, elas foram ganhando experiência sobre a cultura científica do VZ e se posicionando mais criticamente em relação a ela. Passemos às queixas.

A primeira queixa vem da época do ciclo reprodutivo. Durante a gravidez, ouviram de ginecologistas, depois no parto, ouviram de obstetras, e, ao longo do puerpério, foram os pediatras e neurologistas a emitir prognósticos muito categóricos sobre a criança. Na forma de "prazo de validade", como uma avó de micro definiu, essas profissionais disseram que a criança "não sobreviveria"; se sobrevivesse, "vegetaria" inerte sobre uma cama; se vegetasse, "não duraria muito tempo". A maior parte das crianças desafiou todos esses diagnósticos e seguiu vivendo e crescendo. Assertivas categóricas, divergências entre opiniões
12 Diário de campo de Thais Souza, 2017. 
e iatrogenias contribuíram para criar uma atmosfera de desconfiança por parte das famílias. À medida que foram se educando sobre a SCVZ, puderam avaliar as profissionais, escolher com quem se relacionar, derivar aprendizados de todos esses itinerários terapêuticos.

A segunda queixa se refere ao diagnóstico, ou melhor, à falta dele. A primeira geração de mulheres infectadas com o VZ raramente fez um exame de ultrassom gestacional, já que, por um lado, esse exame não integra o protocolo de pré-natal público e, por outro, não havia suspeita de uma epidemia em curso. Mas depois do parto, foram dezenas de exames realizados, nem sempre acompanhados de explicações sobre a razão, o procedimento, a data do resultado. A segunda geração de mulheres, infectada em plena epidemia declarada, já experimentou essa profusão de exames durante e depois da gravidez. Ainda assim, foi comum ouvir delas, "Ninguém me explicou nada no hospital". Numa sala de espera com uma dúzia de mães de micro, Julia lembrou que no começo, à época do nascimento da filha, tinha sido muito difícil, "A gente não entendia nada do que estava acontecendo. A gente ia nas consultas, os médicos falavam e falavam e a gente não entendia aquelas palavras, aquelas explicações todas. Falavam rápido demais, não explicavam o que estavam querendo dizer. E a gente sem entender". "A gente ouvia nos consultórios e voltava para casa sem saber o que tinham dito, né?”, reforçou Lucinha, sentada ali do lado e interlocutora que tinha nos convidado para lhe acompanhar naquele dia e que também esperava pela consulta médica de rotina do filho.

Em geral, não se sentiram confortáveis para fazer perguntas, pedir para que o ritmo das informações fosse mais calmo, checar palavras e termos. E a próxima frase que ouvimos repetidamente foi, "E, claro, fui fuçar na internet”. Ainda outro entendido, o Dr. Google, lhes ajudou a encontrar fotografias, vídeos, depoimentos, reportagens, artigos científicos sobre a microcefalia, depois sobre o VZ e, mais tarde, sobre a SCVZ. E Cíntia, que foi se tornando uma vibrante porta-voz da ciência, aproveitou a internet para avaliar se faria os procedimentos sugeridos pelas médicas, se aceitaria os convites recebidos das cientistas: "As médicas falavam de um exame, falavam uma palavra lá e eu voltava para casa e ia pesquisar na internet, ver o que era, ver se poderiam fazer aquilo na minha filha". Os outros meios de comunicação também ajudaram. Quando perguntamos se a obstetra tinha lhe explicado o que era microcefalia, Irene sacudiu a cabeça, "Explicou nada. Eu não sabia nada. Eu pensei que era só eu. Depois a minha filha [mais velha] viu na televisão e me chamou pra ver também. Foi aí que eu vi que era uma epidemia, que não era só eu" ${ }^{13}$.

Ainda assim, a falta de explicações e de um diagnóstico deixou essas mulheres se sentindo sozinhas até que começaram a se conhecer em salas de espera (semelhantes às que descrevemos aqui), se adicionar nos aplicativos de mensagens e trocar informações e experiências (Lustosa 2020). Foram se fortalecendo com conhecimento, inclusive sobre doutoras, hospitais e projetos de pesquisa mais atenciosos, didáticos e relevantes para suas filhas e filhos. Nesse sentido, Julia, mencionada acima, concluiu, "Hoje, a gente tem muito mais informação, muito mais informação". Ela repetiu várias vezes essa palavra: "A gente não sabia onde
13 Diário de campo de Thais Souza, 2017. 
conseguir mais informação, aonde ir, com quem falar. Hoje não, a gente sabe muito melhor". Dos substantivos inertes, o não e o nada, passaram a verbos de ação, ir, falar, conseguir, saber. Elas também foram, a seu modo, fazer ciência: fuçar, pesquisar, estudar, se informar.

A terceira queixa vinha sendo formulada mais recentemente e derivava de anos de interlocução com a ciência: não receber de volta os resultados. Camille contou, resignada:

Nós somos da pesquisa na [instituição filantrópica] e no [hospital de referência em pediatria]. Mas nunca entregaram o resultado para mim, eu não recebi de volta. Eu já pedi várias vezes, mas desisti de pedir de novo. Eu já até falei assim, "Nem vou pedir mais, né doutora, não vai dar mesmo, né?". A doutora só mostrou assim no computador, foi só assim que eu pude ver. No computador dela, foi quando eu vi pela primeira vez a parte afetada do cérebro do meu filho. Eles tiraram a foto para botar no estudo e me disseram que iam devolver depois. Mas nunca devolveram.

Para mães como Camille, os resultados poderiam ser a ressonância do cérebro, o raio-x da mão ou o hemograma do filho. Tudo isso poderia compor a sua memória e a pasta que carregava cheia de documentos sobre a síndrome do filho. "Resultado", portanto, é outra expressão também polissêmica e amalgamada.

E expressão muito valorizada. A maior parte das famílias nunca recebeu um único resultado e não teve a coragem de pedir, muito menos de insistir e fazer troça como Camille fez. Algumas mães, só souberam “de boca”, com uma informação oferecida pela doutora ao cruzar pelo corredor ou dentro do consultório. Outras, como Camille, puderam ver na tela do computador. Uma ou outra recebeu como um PDF enviado pelo aplicativo de celular. Quase ninguém recebeu uma impressão em papel das mãos da equipe ou enviado via postal, por exemplo. O resultado é compreendido de modo mais amplo porque poderia ter muito mais finalidades do que aquelas previstas inicialmente pela pesquisa. Poderia facultar o acesso a mais especialistas, direitos e benefícios sociais. ${ }^{14} \mathrm{E}$, inclusive, a outras pesquisas. Alguns projetos sobre o VZ exigiam, como condição para participar, o laudo que atestasse a SCVZ ou, como as mães nos diziam, o laudo que ligasse a micro ao Zika.

Nos poucos casos em que o retorno aconteceu, foi reportada também a troca de exames. E, assim, a ciência, seja na figura da doutora, de máquinas ou papéis, ia parecendo cada vez mais exógena e distante, fria e descompromissada. Por outro lado, também conhecemos mães muito entusiasmadas com as pesquisas, como Cíntia, que creditavam ao governo a ausência e a troca de resultados. Não responsabilizavam as pesquisadoras, mas seus superiores que poderiam querer ocultar provas de que o VZ existisse, que a SCVZ fosse uma de suas consequências e, assim, poupar o Estado de qualquer indenização. Nesse mesmo sentido, uma mulher nos explicou que, "por uma deliberação do Ministério Público, os exames não eram devolvidos para que as famílias não pudessem correr atrás de seus direitos".
14 Passe-livre no transporte, vaga no Minha Casa Minha Vida ou na escola, Benefício de Prestação Continuada, Pensão Vitalícia são direitos só garantidos com a apresentação de um dossiê sobre a criança. E os resultados emitidos pelas doutoras, em situação clínica ou científica, eram uma peça central nesse dossiê. 
Não são queixas frívolas, despropositadas nem distantes do making científico. Comunicam um desnivelamento na relação dessas famílias com a ciência, mas também um ideário de ciência: Se elas ajudaram tanto, por que não foram ajudadas de volta na forma de recompensas e parcerias, diagnósticos e resultados? Algumas mulheres, com mais voz, como Cíntia, ou mais humor, como Camille, conseguiram falar de suas expectativas e insatisfações com os projetos de pesquisa, cobraram as cientistas, sugeriram outras formas de trabalho conjunto e até passaram a selecionar mais ativamente quais protocolos científicos integrar. Outras preferiram simplesmente se afastar, perderam a fé na ciência. Não conseguiram mais sustentar, como sugeriu Bela, "a esperança de que elas [as doutoras] vão realizar alguma mudança".

\section{Considerações finais: Quando as famílias antecipam e invertem a rela- ção com a ciência}

Ao cuidar de uma criança com um vírus novo, uma síndrome complexa e um conjunto de deficiências, a esperança era abalada várias vezes, de modo sutil ou drástico, em casa ou na rua. Era também reconstruída muitas vezes, com cacos de novidade, com uma palestra, um exame exibido na tela do computador (Fleischer 2020a). A ciência era sedutora porque convidava todas ao seu redor a imaginar outras possibilidades. Por isso, a ciência foi onde muitas das interlocutoras, como Cíntia, Camille e Mariana, se nutriram por muitos anos. Embora fonte significativa, não era a única, como Bela, Julia, Lucinha e Irene foram percebendo aos poucos.

Essa nutrição indica o primeiro dos três tipos mais comuns de relacionamento com a ciência biomédica, segundo Rabeharisoa e Callon (2002). O tipo "auxiliar", onde há "uma divisão estrita de papéis e missões" entre pesquisadoras e sujeitos pesquisados (Rabeharisoa et al. 2012, 20), onde pacientes e cuidadores "são esperados pelos profissionais para serem cooperativos para que seu tratamento [e pesquisa clínica] possa acontecer sob as mais favoráveis condições técnicas" (Rabeharisoa e Callon 2002, 60). Nesse tipo de relacionamento, as ações das pacientes e de suas cuidadoras devem ser "meras extensões do que é feito pelas médicas" (idem).

A intensidade com que a ciência chegou foi invasiva, repetitiva, enfadonha, mas deu acesso a um grande conjunto de doutoras. Mesmo havendo queixas, a ciência e as cientistas se mantiveram como um valor e por isso havia o empenho em encontrar doutoras com quem ajudas, recompensas e parcerias poderiam ser trocadas a contento e uma relação foi sendo estabelecida entre as partes. Nesse caso, a médica se sentiria mais constrangida de oferecer opiniões muito categóricas e pouco detalhadas; a família se sentiria menos constrangida de fazer perguntas para entender as informações; e caso não chegassem, os resultados poderiam ser cobrados mais corriqueiramente, como Camille vinha fazendo.

Quer dizer, foi ficando insustentável "dar plena vazão aos desejos e projetos das profissionais", como no tipo de relação meramente "auxiliar" (Rabeharisoa e Callon 2002, 61). E, uma maior seletividade sobre as cientistas e suas propostas foi 
importante para que essas famílias não ficassem totalmente "despojadas de sua influência", caminhando para o segundo tipo de relação com a ciência, que esses autores também chamam de "parceria" (idem). Se não notamos uma participação mais intensa no desenho inicial das pesquisas sobre VZ ou SCVZ, ao menos a postura das famílias em relação à ciência foi se modificando. Mais e mais, a experiência das famílias, no sentido "de saber o que significa viver com a doença (...), ditada pela sua intimidade com a doença” (idem, 62), foi lhes garantindo mais legitimidade e autorizando a parear com as doutoras. Fomos notando práticas como oferecer detalhes, a partir da "ciência doméstica", para que "as características" da SCVZ pudessem ser mapeadas; comparar e complementar informações durante os encontros nas salas de espera; priorizar aqueles consultórios com atmosferas de aprendizado mútuo entre famílias e especialistas; cobrar resultados para que a cooperação pudessem continuar em curso (Rabeharisoa e Callon 2003, 195).

Amadurecer opiniões sobre a ciência e as cientistas, na forma das três queixas aqui descritas, foi também uma forma de participar ativamente desse cenário. Estavam observando, avaliando, reagindo aos convites, protocolos, agulhas. E, diante de ruídos e discordâncias, em vez de deixar a cena, continuaram marcando sua presença, exigindo um bom atendimento científico para suas crianças. Estavam desenhando melhores condições éticas para a ciência do VZ a partir de quem vivia diretamente a SCVZ. Parece-nos muito estimulante ver sujeitos de pesquisa sugerindo aprimoramentos aos sujeitos pesquisadores, ampliando a forma de produzir ciência. Mas essa postura mais crítica não chegava a ilustrar totalmente o terceiro tipo de relacionamento, a "oposição" à ciência, onde "se rejeita qualquer definição de seu estado pela comunidade científica e médica” (Rabeharisoa e Callon 2003, 195). Ainda interessadas em manter alguma relação com a ciência, as mães de micro que conhecemos estariam prenunciando "novas relações entre ciência e sociedade, entre quem produz conhecimento e quem se destina a dele se beneficiar" (Rabeharisoa e Callon 2002, 63). Se, de início, essas famílias foram apenas convidadas pelas doutoras para integrar seus projetos de pesquisa ("auxiliar"), mais recentemente, aquelas já se percebiam como interlocutoras mais atuantes ("parceiras" e, muito pontualmente, "opositoras") do que essas últimas talvez imaginassem.

Então, em vez de esperar que os resultados viessem somente das cientistas, notamos uma antecipação e uma inversão. Ao observarem atentamente a produção da ciência, ao relatarem sobre suas experiências dentro dessa produção e ao comunicarem suas discordâncias sobre essas experiências, as famílias já estavam antecipando resultados às cientistas. As famílias iam se tornando cientistas que estudavam cientistas, invertendo os papéis de quem pergunta e quem responde. Mulheres como Cíntia, Mariana e Camille não apenas ajudaram a ciência com o material orgânico de seus filhos e filhas, mas também sugeriam que a ciência realizasse suas práticas de modo mais cuidadoso e equitativo ("de mãos dadas"). Esse pode ser um resultado inesperado pelas doutoras, se ainda estivessem acomodadas numa relação de enunciação unidirecional, de dentro da universidade para o mundo de fora, acostumadas a serem os sujeitos que miram e interpretam 
os objetos. Mas não tomo a tipologia proposta pelos autores como fixa porque não afasta os momentos em que as famílias de micro oscilavam entre mero auxílio, a relação mais comum, e uma certa desesperança com a ciência, relação mais recente. E ainda, como as lideranças Ana Caroline e Fernanda mostraram, as parcerias dependiam de muitos esforços coletivos e realizados de todos os lados para que o "modelo de delegação" e o "grande divisor" entre "know-how especializado e experiência leiga" (Rabeharisoa e Callon, 2003) pudessem ser revistos.

Neste artigo, amparadas por antropólogas que vêm estudando o envolvimento de pacientes e acompanhantes com a ciência, buscamos entender como foi vista a intensa chegada das cientistas do VZ e SCVZ na Região Metropolitana do Recife, algumas das razões para as famílias de micro aceitarem seus convites e três críticas recorrentes que formulavam sobre esses encontros. Essas imagens eram variadas e eloquentes e, mais importante, a partir daí, as relações travadas com as cientistas também foram se diversificando. Nessa intensa construção de relações científicas, as famílias também comunicaram suas análises: o que imaginavam como a "boa ciência", a "boa cientista" e como poderia "ser bom para os dois lados". Quando se frustravam nesses encontros científicos, algumas famílias passaram a evitar os próximos convites para integrar projetos de pesquisa, mas isso não significa que deixassem de frequentar consultórios de especialistas, de oferecer medicamentos sofisticados para paliar os sintomas das crianças com a SCVZ ou, mais recentemente, de ansiar pela chegada das vacinas contra a covid-19 à faixa etária infantil.

A fé na ciência permanecia, mas não incondicionalmente. $\mathrm{E}$, em tempos tão sombrios vividos pela ciência neste país, vale reforçar: tecer críticas não é o mesmo que negar a ciência. Como muitas dessas famílias no Recife, também somos entusiastas da ciência, mas não de qualquer ciência, nem realizada a qualquer custo $^{15}$. Informadas pela sua experiencia como mães, cuidadoras e acompanhantes de sujeitos de pesquisa, essas mulheres também estavam a fazer ciência, ao alimentar com material orgânico a ciência do VZ, da SCVZ e, mais do que tudo, a ciência que resultava a partir de todos os atores que aí haviam se encontrado. Participar da ciência era, de modo nada passivo, ampliar as escalas de esperança por onde poderiam imaginar o futuro de suas crianças. Gerava uma expectativa imediata ao doar um pouco de urina e receber uma recompensa concreta na forma de fraldas ou uma cesta básica. Permitia ansiar por terapias e acompanhamento médico continuado, a partir da parceria entre famílias e universidades. Ou até esperar, num ato mais altruísta ou humanitário, a partir de uma acepção geral de ajuda, que o sangue da sua filha pudesse beneficiar muitas outras crianças com a mesma condição de saúde, ao redor da cidade e também no futuro. Etnografar esses encontros e relacionamentos com a ciência visa, principalmente, afirmar que ela muito se beneficia sendo coproduzida e seguindo como assunto debatível publicamente por todas nós.
15 E nem em consonância com o que Sônia Maluf chamou de uma "reemergência (...) de uma visão reducionista do campo científico, que exclui perspectivas que não cabem em um formato positivista e determinista da saúde" (2021, 283, nota 29). 
Soraya Fleischer

\section{Referências}

Barros, Alessandra S. S. 2021. "Deficiência, Síndrome Congênita do Zika e produção de conhecimento pela antropologia". Revista Scientia 6(1): 142-63.

Castro, Rosana. 2020. Economias políticas da doença e da saúde: uma etnografia da experimentação farmacêutica. São Paulo: Hucitec.

Diniz, Debora. 2016. Zika: Do sertão nordestino à ameaça global. Rio de Janeiro: Civilização Brasileira.

Fleischer, Soraya. 2020a. "Circulação de esperança em tempos de Síndrome Congênita do Vírus Zika no Recife/PE". In Desigualdades e Políticas da Ciência, org. Debora Allebrandt, Nádia Meinerz e Pedro Nascimento, 325-62. Florianópolis: Casa Verde.

Fleischer, Soraya. 2020b. "Doutores”. In Micro: Contribuições da Antropologia, org. Soraya Fleischer e Flávia Lima, 77-88. Brasília: Athalaia.

Fleischer, Soraya. "A multicausalidade da microcefalia (Recife, Pernambuco)". No prelo.

Fleischer, Soraya, e Flávia Lima, orgs. 2020. Micro: Contribuições da Antropologia. Brasília: Athalaia.

Latour, Bruno. 2000. Ciência em ação: como seguir cientistas e engenheiros sociedade afora. São Paulo: UNESP.

Lustosa, Raquel. "Mulheres”. 2020b. In Micro: Contribuições da Antropologia, org. Soraya Fleischer e Flávia Lima, 39-50. Brasília: Athalaia.

Maluf, Sônia. 2021. "Janelas sobre a cidade pandêmica: desigualdades, políticas e resistências". Tomo 38: 251-85.

Moreira, Tiago. 2014. "Understanding the role of patient organizations in health technology assessment". Health expectations: an international journal of public participation in health care and health policy 18(6): 3349-57.

Moreira, Tiago, Orla O'donovan, e Etaoine Howlett. 2014. "Assembling dementia care: Patient organisations and social research". BioSocieties 9: 173-93.

Nunes, João Arriscado, Ângela Marques Filipe, e Marisa Matias. 2010. "Os novos actores colectivos no campo da saúde: o papel das famílias nas associações de doentes". Alicerces: 119-28.

Pols, Jeannette. 2014. "Knowing patients: turning patient knowledge into science”. Science, Technology, \& Human Values 39(1): 73-97.

Rabeharisoa, Vololona, Tiago Moreira, e Madeleine Akrich. 2014. "Evidence-based activism: Patients', users' and activists' groups in knowledge society”. BioSocieties 9: $111-28$.

Rabeharisoa, Vololona, Michel Callon, Angela Marques Filipe, João Arriscado Nunes, Florence Paterson, e Frédéric Vergnaud. 2012. "The dynamics of causes and conditions: the rareness of diseases in French and Portuguese patients' organizations' engagement in research". CSI Working Papers Series 026. Paris: Centre de Sociologie de l'Innovation (CSI), Mines ParisTech.

Rabeharisoa, Vololona, e Michel Callon. 2007. "The Growing Engagement of Emergent Concerned Groups in Political and Economic Life". Science Technology \& Human Values 33(2): 230-61.

Rabeharisoa, Vololona, e Michel Callon. 2003. "Research 'in the wild' and the shaping of new social identities". Technology in Society 25: 193-204. 
Soraya Fleischer

Rabeharisoa, Vololona, e Michel Callon. 2002. "The involvement of patients' associations in research". International Social Science Journal 54: 57-63.

Scott, Parry, Marion Quadros, Ana Claudia Rodrigues, Luciana Campelo Lira, Silvana Sobreira Matos, Fernanda Meira, e Jeíza Saraiva. 2017. "A epidemia de Zika e as articulações das mães num campo tensionado entre feminismo, deficiência e cuidados". Cadernos de Gênero e Diversidade 3(2): 73-92.

Simas, Aissa. 2020. "Ciência, saúde e cuidado: Um estudo antropológico sobre a pesquisa clínica no contexto da epidemia do Zika (Recife/PE)". Dissertação de mestrado, Universidade de Brasília. 